\title{
A comprehensive philosophical approach to Qohelet's epistemology
}

\begin{tabular}{|c|}
\hline $\begin{array}{l}\text { Author: } \\
\text { Jaco Gericke }{ }^{1}\end{array}$ \\
\hline $\begin{array}{l}\text { Affiliation: } \\
{ }^{1} \text { Faculty of Humanities, } \\
\text { North-West University, } \\
\text { Vaal Triangle Campus, } \\
\text { South Africa }\end{array}$ \\
\hline $\begin{array}{l}\text { Correspondence to: } \\
\text { Jaco Gericke }\end{array}$ \\
\hline $\begin{array}{l}\text { Email: } \\
\text { 21609268@nwu.ac.za }\end{array}$ \\
\hline $\begin{array}{l}\text { Postal address: } \\
\text { PO Box 1174, Vanderbijlpark } \\
\text { 1900, South Africa }\end{array}$ \\
\hline $\begin{array}{l}\text { Dates: } \\
\text { Received: } 25 \text { Nov. } 2014 \\
\text { Accepted: } 01 \text { Feb. } 2015 \\
\text { Published: } 23 \text { Apr. } 2015\end{array}$ \\
\hline $\begin{array}{l}\text { How to cite this article: } \\
\text { Gericke, J., 2015, } \\
\text { 'A comprehensive } \\
\text { philosophical approach to } \\
\text { Qohelet's epistemology', } \\
\text { HTS Teologiese Studies/ } \\
\text { Theological Studies 71(1), } \\
\text { Art. \#2868, } 9 \text { pages. http:// } \\
\text { dx.doi.org/10.4102/hts. } \\
\text { v71i1.2868 }\end{array}$ \\
\hline $\begin{array}{l}\text { Copyright: } \\
\text { (C) 2015. The Authors. } \\
\text { Licensee: AOSIS } \\
\text { OpenJournals. This work is } \\
\text { licensed under the Creative } \\
\text { Commons Attribution } \\
\text { License. }\end{array}$ \\
\hline
\end{tabular}

Read online:

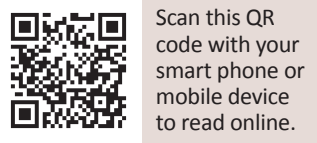

An increasing number of studies have seen the light over the last few decades concerning the epistemology of the book of Ecclesiastes. The extant research seems to be limited to try to find a suitable philosophical profile for Qohelet's concept of knowledge whilst ignoring a whole array of topics and theories in contemporary analytic epistemology. The available research thus reveals an 'inside-out' approach that is, reading Qohelet and then seeking to link his thought to a particular epistemological stance. In this study, however, an 'outside-in' approach is opted for that involves noting all the various issues in epistemology and then comparing each with what, if anything, Qohelet assumed in relation to the specific matter at hand.

\section{Introduction}

Research on the epistemology of Qohelet has become an increasingly popular sub-theme in Ecclesiastes studies (see Schellenberg 2002:35-73; cf. Sneed 2012:13-20). This trend can be seen as a belated continuation and culmination of modernity's exchange of metaphysical concerns for epistemological interests (e.g. Descartes 1641; Hume 1751; Locke 1689). It also represents drafting in the wake of the epistemological turn in 20th-century, right-wing analytic philosophy of religion (see Wolterstorff 1999:303-324; especially so-called 'Reformed Epistemology').

In Old Testament Forschungsgeschichte, the epistemological turn in Ecclesiastes studies tends to be popularly attributed to the ideas first put forward by Fox (1987:137-156). O'Dowd (2009:138) and Sneed (2012:42), however, have recently pointed out that the concern with Qohelet's epistemological assumptions can be traced further back to older attempts to relate the book to Greek philosophical thinking (e.g. Nordheimer 1838:197-219; Pfeiffer 1934; Ranston 1925; and classically Braun (1973) and Hengel 1974).

Be that as it may, since the follow-up work by Fox (1989:79-117; 1998:225-238; 1999:71-86), other scholars who have joined the discussion on Qohelet's epistemology include Bartholomew (1998:4-20; 2009:passim), Crenshaw (1984:31-56; 1998:205-224), Enns (2011:118-124), Frydrych (2002:passim), Imray (2009), O’Dowd (2009:138-152), Pinker (2013:163-170), Schellenberg (2002:35-73), Sciumbata (1996:235-249) and Weeks (2012).

\section{A summary of contested issues in epistemological perspectives on Qohelet}

In many of the aforementioned studies, epistemology is not the only concern but rather a subsection of the particular work. Still, a clear and well-defined area of sub-specialisation seems to have come into being, and as is typical of all emergent scholarly concerns, there exists a variety of popular research topics with regard to which there is often little consensus. These include, inter alia, the following:

1. There is no agreement at all as to whether Qohelet has a concern with epistemology or not. Whilst some researchers claim that epistemology is central to the book, others distinguish this from a quest for knowledge which is not identical to epistemological reflection.

2. Historically, however, the debate as to the cultural context of Qohelet's epistemological assumptions was first. It entails questions such as if there is a relationship with Greek philosophy and, if so, what the relationship is or whether to locate Qohelet's epistemology wholly within an ancient Near-Eastern setting.

3. As always, there is a dispute as to the exact extensions and intensions of key epistemological terms in Ecclesiastes as these relates to the phenomenon and the ontology of knowledge.

4. There is the ideological debate as to whether Qohelet's epistemology is ironic in a polemical (and especially theological) sense or not. Here, fundamentalist and critical readings differ in a most fundamental way as to the message of the book. 
5. A major discussion point concerning Qohelet's epistemology is whether, in what sense and to what extent his methods can be labelled empiricist. It also includes a discussion on the role of non-empirical knowledge (often called 'a priori', 'revelation' or 'tradition').

6. There is the debate as to whether and, if so, in what sense and to what extent Qohelet can be classified as a sceptic with a pessimist epistemology as opposed to some or other more positive view of the sources, objects, limits and acquisition of knowledge.

7. Another point of interest is the question as to what extent Qohelet's epistemological assumptions are coherent and, if not, what the causes for the discrepancies are, be these sources or redactions, normal human inconsistency or the cumulative effect of combining 'early' and 'late' Qohelet's views.

8. The question as to epistemological coherence is also related to another question concerning the relationship between Qohelet's epistemology and that of other biblical books, namely whether this relationship is supplementary, complimentary or contradictory.

9. Related to the issue stated above is the question as to which extent Qohelet's epistemology represents a progressive break or revolt from or a radical regression to or a continuation of traditional wisdom epistemology.

10. There is the interest in how Qohelet's epistemology is related to his theology, his anthropology, his ethics and his axiology. Other popular themes to which his epistemology is correlated is his view on death, joy and time.

Readers interested in more detailed referenced overviews of the history of these problems are referred to O'Dowd (2009:138-142), Schellenberg (2002:35-60) and Sneed (2012:13-20) (also cf. Schoors 1998:passim). Additional and somewhat more minor related issues are addressed in the research on the epistemology in Ecclesiastes. These include the extent to which Qohelet is supposed to believe in the autonomy of the human subject; what he considers to be the sources, scope and limits of knowledge; what the methods and objects of the quest for knowledge are as well as the book's assumptions about the ontological status of knowledge claims. There is no consensus on any of these matters although, for each, there is usually a majority view.

\section{The research problem, objectives and assumptions of this study}

The above represent some of the major concerns in the available research on Qohelet's epistemology. Readers familiar with Ecclesiastes research will notice that most of these problems are related to those outlined in general research on Qohelet. In addition, as epistemological reflection on Qohelet, these concerns seem to suggest a rather reductive philosophical perspective. That is, the sum total of these concerns does not reflect an in-depth philosophical analysis of Qohelet's epistemology. At best, scholars merely analyse the book's concept of knowledge in the context of linguistic, literary, historical, sociological and theological frameworks.
Stated differently, available approaches to Qohelet's epistemology are not philosophical but linguistic, literary, historical, sociological and theological. As such, they approach the subject from the 'inside-out', namely from Qohelet to a seemingly related parallel epistemological perspective or theory. In this way, Ecclesiastes scholars appear to assume that the book's epistemology begins and ends with traditional biblical exegesis. Such an approach is not necessarily altogether wrong, but what is needed to supplement extant research is an 'outside-in' approach.

In other words, might it not be more informative if the exegete begins with the discipline of epistemology (in its entirety as a philosophical subfield with a variety of topoi) and by way of comparative philosophy seek to determine what, if anything, Qohelet might have assumed in relation to various epistemological themes (with no or negative answers also providing meaningful information). This format will then neither entail a commentary on Ecclesiastes nor an approach designed around the book's own explicit contents. Instead, one approaches the textual data via the array of epistemological themes typically found in outlines of the subfield within contemporary analytic (as opposed to continental) philosophy.

In other words, a purely philosophical (i.e. comparative epistemological) perspective on Qohelet is needed in the sense of being more focused on issues that epistemologists proper are actually currently discussing (cf. Steup 2005:n.p.; Truncellito 2007:n.p.). Such a reading is hermeneutically warranted even if Qohelet is not technically to be classified as a philosopher or epistemologist in the stereotypical Western or Eastern senses of these roles. What cannot be denied, however, is that the book of Ecclesiastes does contain takenfor-granted folk-epistemological assumptions which can be analysed and clarified from a descriptive philosophical perspective. In this manner, research on Qohelet's epistemology can become philosophically more nuanced and comprehensive. Epistemology is after all a philosophical concern, and epistemological research on Qohelet thus needs to take cognisance of what philosophers proper have discussed in relation to their subject.

Being descriptive and aimed at clarification rather than justification or criticism, the above-noted philosophical approach can bracket the question of whether either Qohelet or a given philosophical theory is epistemologically correct. The aim of such a study would not be to see how Qohelet can contribute to contemporary epistemological theorising but rather how the latter can elucidate the former. This means that all the various epistemological themes and theories can simply be put on the table and, in the manner of comparative philosophy, the exegete can then enquire as to if and how Qohelet's assumptions about knowledge can be related to - and agree or differ from - the particular philosophical topic.

From the outset it should be noted that, in the present attempt to provide a properly philosophical introduction to 
the epistemology of Qohelet (as opposed to seeing Qohelet as presenting a ready-made epistemology), it is impossible to be as detailed as one would wish on the level of exegesis. This is the necessary albeit unfortunate consequence of introducing and summarising the new and more strictly philosophical approach to Qohelet's epistemology in the limited space of a journal article as opposed to, say, a monograph. As a result, it is not possible to bring to bear all the technical theoretical distinctions in epistemological questions, problems, methods, perspectives and so on that would be part of a more extended version of this study. Neither can examples from the text (which should not be confused with 'proof-texts') be discussed in-depth. Much more nuance, variety of topics and conceptual refinement are certainly possible (for a detailed introduction of the scope of contemporary epistemology, see Audi 2005; BonJour 2010; Dancy \& Sosa 1993; Pollock \& Cruz 1999; Steup \& Sosa 2005).

\section{Basic questions for a comprehensive, comparative folk-epistemological analysis}

In popular epistemology, two dimensions of inquiry with the necessary subsections are often distinguished, and these will provide the framework for the present inquiry (cf. Truncellito 2007:n.p.). They concern 'knowledge' and 'justified belief', based on a traditional epistemic definition going back to Plato according to which knowledge can in fact be defined as justified true belief (cf. Plato 1997:870-897). Firstly, as the comprehensive study of textual assumptions about knowledge, our analysis of Qohelet's epistemology might perhaps be concerned with theories related to the following epistemologically basic questions:

1. Did Qohelet assume there to be necessary and sufficient conditions of knowledge?

2. What folk-epistemological assumptions in Qohelet relate to sources of knowledge?

3. What folk-epistemological assumptions in Qohelet relate to the structure of knowledge?

4. What folk-epistemological assumptions in Qohelet relate to the limits of knowledge? (see Steup 2005:n.p.)

Whilst some studies do address related issues, none of these focus on the folk-philosophical presuppositions underlying Qohelet's explicit rhetoric. Secondly, as the study of Qohelet's assumptions about justified belief, the study of Qohelet's epistemology means that the following additional basic questions also arise:

1. What folk-epistemological assumptions in Qohelet relate to the concept of justification?

2. What, according to Qohelet, makes justified beliefs justified?

3. Was justification assumed by Qohelet to be internal or external to the mind?

In addition to these basic questions related to the Platonic definition of knowledge as justified true belief, there is a host of more specific theoretical perspectives in epistemology to be related to Qohelet's folk-epistemological assumptions.

\section{Qohelet and types of knowing}

Since the work of Russell (1910-11:108-128), some epistemologists have made a distinction between a) 'knowing that' (knowledge by description) and b) 'knowing how' (knowledge by acquaintance). We may therefore ask whether, in Qohelet, we find a distinction between these types of knowing. An example of a) would be Qohelet claiming to know that something is the case regarding states of affairs in the world of the text. An instance of b) would be Qohelet referring to someone's knowledge of how to do something. The above distinction between types of knowledge is never explicitly made by Qohelet but can be teased from in the text. Statistically we find proportionately more references to a) or 'knowing that' (consistently 'ידע| + כי'), as this is reflected in the English translations from the RSV (all emphases are by the author):

1. I know that there is nothing better for them ... (3:12)

2. I know that whatever God does endures forever ... (3:14)

3. ... for they do not know that they are doing evil (4:17)

4. ... your heart knows that many times you have cursed others $(7: 22)$

5. ... yet I know that it will be well with those who fear God $(8: 12)$

6. For the living know that they will die ... (9:5)

7. But know that for all these things God will bring you into judgement (11:9)

By contrast to the above, explicit references to 'knowing how' $((\mathrm{x}) ל$ + ידעy $)$ are relatively rare and mostly incidental, for example:

1. What does the poor man have who knows how to conduct himself? (6:8)

2. So that he does not know [how to find] the way to the city $(10: 15)$.

Other less explicit possible allusions to 'knowing how' do feature, however. The following are examples of these:

1. I said to myself, 'I have acquired great wisdom, surpassing all who were over Jerusalem before me; and my mind has had great experience of wisdom and knowledge.' (1:16)

2. And I applied my mind to know wisdom and to know madness and folly. I perceived that this also is but a striving after wind. (2:17)

3. When I applied my mind to know wisdom, and to see the business that is done on earth, how neither day nor night one's eyes see sleep (8:16)

Clearly the above refers to experiential knowledge and skill and as such designates knowledge by acquaintance. This suggests that, whilst philosophers have stressed the importance of the distinction between knowledge by description and acquaintance, the latter also having been shown to be implicitly present in Qohelet, it was not especially notable or important for the author. 


\section{Qohelet's assumptions about belief}

Whilst in everyday language, a 'belief' is typically an expression of faith and/or trust in a person, power or other entity, our concern lies with the technical epistemological sense of the word. In this broader sense, 'belief' simply means the acceptance as true of any cognitive content, that is, to believe is to accept as true. In light of this, what then are Qohelet's assumptions about epistemic belief, and what is the role of belief in the book's discourse? Relatively obvious is that Qohelet like everyone else held a number of beliefs about states of affairs, despite all his doubts and misgivings about many things. The totality of these beliefs themselves would be impossible to list as they pertain to an indefinite number of things, expressible in more than one way. They involve everything he affirms or denies as being the case - the epistemological content presupposed, explicit and implied in all of his words.

With regard to Qohelet's assumptions about the phenomenon of belief itself, it may be noted that the Hebrew word for belief in the cognitive sense does not occur in the text. However, the concept is presupposed, particularly in his rhetorical questions inviting a suspension of belief. These

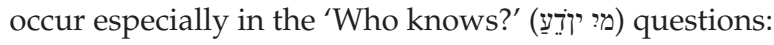

1. ... who knows whether he will be a wise man or a fool? (2:19)

2. Who knows whether the spirit of man goes upward ...? (3:21)

3. ... who knows what is good for man $(6: 12)$

4. ... who knows the interpretation of a thing? (8:1)

Here, one clearly finds the true belief that $x$ is impossible to verify and that belief about $x$ should be bracketed. In this sense, we can also see in Qohelet the assumption that belief can be distinguished from knowledge and that, whereas beliefs are not necessary knowledge, knowledge is assumed to involve justified true beliefs. In the 'who knows?' texts, one is assumed not to know the truth if one is not justified in believing it.

\section{Qohelet's assumptions about truth}

What are Qohelet's assumptions about truth in the context of belief? Here, we are not interested in Qohelet's folkphilosophical theory (or theories) of truth (which might seem to involve both correspondence and pragmatist ideas). Again, the word truth as such does not occur in Qohelet (the root of which is the same as that of belief in Hebrew). Yet again, we can say that Qohelet only presupposes the concept as he assumes his own beliefs to be true in the sense of corresponding to states of affairs in the world 'under the sun'.

As noted above, Qohelet assumes that the truth of someone's belief is not a prerequisite for holding the belief. However, for Qohelet, if something is actually known, categorically, it cannot be false. Consider the following example:

Whatever has come to be has already been named, and it is known (וְנוָֹ what man is, and that he is not able to dispute with one stronger than he. $(6: 10)$
Thus, according to Qohelet, if people believe that they can argue with the divine, we may say they believe that they can do it but that this belief is mistaken. It would not be accurate to say that they know that they can dispute with God because plainly Qohelet assumes that they cannot. By contrast, if they can dispute, then Qohelet might say that he believed that he could argue his point, whereas now, after proving it to himself (by arguing), he knows it to be possible. As for Qohelet, what we do find is that he often (but not always) does one of three things when it comes to possessing knowledge and, therewith by implication, truth:

1. claiming to know that $x$

2. some instances of reporting what he thought (said in his heart) about $x$

3. claiming to have found $x$

The first of the above contexts for truth to emerge has already been dealt with above. I shall deal with the third below in the section on justification. For now, I focus on what Qohelet assumes to be true beliefs in some sentences Qohelet thought (spoke to himself 'in his heart'). This pertains only to sentences where what Qohelet said in his heart is a proposition that he is affirming and not a rhetorical question (sometimes mixed with declarative propositions) or self-command (e.g. 2:1; 7:23) as also occur from time to time. Though some knowledge is implicit, even here, it is only the more declarative propositional statements that represent the content of overt belief statements as conclusions following an effort to obtain knowledge:

1. I said to myself, 'I have acquired great wisdom.' (1:16)

2. I said of laughter, 'It is mad.' (2:2)

3. Then I said to myself, 'What befalls the fool will befall me also ...' (2:15)

4. I said in my heart, 'God will judge the righteous and the wicked ...' (2:17)

5. I said in my heart with regard to the sons of men that God is testing them ... (3:18)

6. I said, 'This is also vanity.' (8:14)

These 'I said ... $x^{\prime}$ ' expressions presuppose prior epistemological activity. The expressions of thought all contain beliefs that Qohelet appears to have come to believe to be true in the sense of correspondence between language and facts. Whether he took them all to represent knowledge is an open question, depending on the epistemological model we infer with him. After all, (1) contradicts (7:24-26), (2) contradicts all his invitations to be happy and enjoy life, (3) is an expectation about the future that cannot be proven, (4) involves a theological statement which one could argue he is simply restating, and (5) is again his belief, but whether he assumed it to be knowledge in the sense of justified and true is unclear if we assume too rigorous standards of justification. More directly related to alleged 'justified' true belief qua knowledge are expressions in which Qohelet relates what he has 'found' (i.e. concluded). 


\section{Qohelet and justification}

In the classic definition of knowledge as justified true belief, to know that a proposition is true, one must have a good reason for believing it to be such. This is also true for many ideas expressed by Qohelet, which, as we shall see, he seeks to justify by an appeal to what he considers evidence of some sort. This process of belief justification by Qohelet seems presupposed in the following text: And besides that Qohelet was wise, he also taught the people knowledge (ַㅗ)

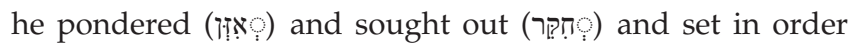
(החיקוּן Proverbs. (12:9)

The same diligent pursuit of knowledge seems presupposed in the following:

1. And I applied my heart to seek and to search (לדרְוּש וְלָתוּר) out by wisdom concerning all things that are done under heaven. (1:13)

2. All this have I tried (נִִּיתי) by wisdom. (7:23)

In both cases, working 'in/by' wisdom seems to have some epistemological import. Whereas 'weighing' seems to involve some sort of attempted justification or confirmation, studying and arranging can (but need not) refer to the same epistemological process. This is further supplemented - as far as presupposing justification is concerned - with the idea of having found something. Here 'to find' (מצא) does not refer merely to come across or encounter but to come to via a process of purposeful searching and questioning:

1. And I found more bitter than death the woman whose heart is snares and nets. (7:26)

2. Behold, this is what I found, says Qohelet, adding one thing to another to find the sum. (7:27)

3. Behold, this alone I found, that God made man upright, but they have sought out many devices. (7:29)

What, then, according to Qohelet, made justified beliefs justified?:

1. Based on the epistemological processes described in Qohelet - and he does not seem to be consistent here he seems to be partly an evidentialist at times, that is, in some cases what is assumed to justify a belief is the possession of some form of evidence.

2. In contrast, Qohelet also show signs of being a reliabilist at times in that he would deny that justification is solely a matter of having suitable experiences. Rather, Qohelet at times presupposes that a belief is justified if, and only if, it results from a cognitive origin that is reliable (e.g. a wise man's heart).

In contemporary epistemology, an extensive debate concerns itself with whether such justification is internal or external. How are we to understand these claims in relationship to Qohelet's epistemology?:

1. Qohelet could be construed as an externalist if, for him, factors deemed 'external' (meaning outside of his psychological states) could be conditions of knowledge and if a causal link can be assumed between the belief and the state of the external world.

2. Qohelet could alternatively be seen as having internalist assumptions if he presupposed that some knowledgeyielding conditions are within his own psychological states.

Of course, which of these categories, if any, provides an exhaustive and perfect view of Qohelet's epistemological assumption is the question to which the philosophical analyst has to attend.

\section{Qohelet, Gettier problems and responses}

Ever since Plato, knowledge was popularly defined as justified true belief. A few decades ago, however, Gettier (1963:121-123) argued that there are situations in which one's belief may be justified and true yet fail to count as knowledge. In other words, justified belief in a true proposition is necessary but not sufficient for that proposition to be known, for example, when a person's belief of what is wrong can coincidentally be correct without his or her having the actual knowledge on which to base it. Do we have any Gettier-type cases in Qohelet? This is not easy to demonstrate. However, consider the following:

Guard your steps when you go to the house of God; to draw near to listen is better than to offer the sacrifice of fools; for they do not know that they are doing evil. $(5: 1)$

In this scenario and according to Qohelet, the fools know what the right ways are but do not know that they are not doing it. This is similar to though not strictly Gettier-type reasoning:

1. Fools believe that doing evil during sacrificial rituals is wrong.

2. What fools believe in this regard is true.

3. Fools are moreover justified in so believing.

Yet, whilst having justified, true beliefs about doing evil when sacrificing, they are fools precisely because they themselves are doing this evil yet do not know that they are doing it. Qohelet claims a lack of knowledge on their part with reference to doing evil despite their justified, true belief about doing evil. Consider the second example:

In the morning sow your seed, and at evening withhold not your hand; for you do not know which will prosper, this or that, or whether both alike will be good (11:6)

According to Qohelet, a sower probably believes that one or more of the times of sowing will be good. Also, according to him, this is justified and true since one of the times will indeed be good. Yet one does not have knowledge in the sense that, according to Qohelet, one does not know when the sowing will be good or which of one's ventures will bring success even though one has correctly predicted that one of them will. The same is true in the following case where justified, true belief regarding outcome does not equate to 
having knowledge: Give a portion to seven, or even to eight, for you know not what evil may happen on earth. (11:2)

Again, here is a case of justified true belief but no knowledge. One justifiably believes that evil will happen, and the belief is true, but one does not know what will actually happen.

In all the above examples, Gettier cases may or may not be present, depending on how the meaning of the texts is reconstructed. Hence the examples are less than perfect. Be that as it may, much of contemporary epistemology consists of responses to Gettier's challenge to the traditional definition of knowledge as justified true belief. Usually, these responses involve attempts to provide a definition of knowledge alternative to the classical one, either by recasting knowledge as justified true belief with some additional fourth condition or as something else altogether:

1. One response perhaps present in Qohelet relates to infallibalism which would have him assuming that, to qualify as an item of knowledge, a belief must not only be true and justified but the justification of the belief must necessitate its truth.

2. A second possible response would involve Qohelet assuming indefeasibility as a candidate for a fourth condition of knowledge, that is, the assumption that there should be no defeating truths for the reasons that justify a belief.

3. A third response perhaps present in Qohelet might be the assumption that knowledge is sui generis in that it just is what it is and is not to be broken down into the concepts of justified true belief plus some extra condition(s).

Which, if any, of these views represents Qohelet's implied perspective(s) on Gettier cases (whether present in the text or not) is another question to which and comprehensive epistemological approach to Qohelet could attend.

\section{Qohelet and the value problem}

Qohelet most certainly had assumptions about the value of knowledge (or its lack). Whilst throughout his quest to know what is good for humans to spend their days on he does assume knowledge to have some practical value, he also puts to the reader the problem of the utility function of knowledge in the context of teleology:

I said to myself, 'I have acquired great wisdom, surpassing all who were over Jerusalem before me; and my mind has had great experience of wisdom and knowledge.' And I applied my mind to know wisdom and to know madness and folly. I perceived that this also is but a striving after wind. For in much wisdom is much vexation, and he who increases knowledge increases sorrow. (1:16-18)

The problem of value relates not only to personal suffering but also to injustice in the context of labour as the following text shows:

Because sometimes a man who has toiled with wisdom and knowledge and skill must leave all to be enjoyed by a man who did not toil for it. This also is vanity and a great evil. (2:21)
For to the man who pleases him God gives wisdom and knowledge and joy; but to the sinner he gives the work of gathering and heaping, only to give to one who pleases God. This also is vanity and a striving after wind. (2:26)

In other words, for Qohelet, knowledge is not particularly valuable for its own sake and ought to be considered in conjunction with matters pertaining to teleology, justice and value. After all, knowledge is neither a necessary nor sufficient condition for what is good as can be seen in the relatively more enviable state of the stillborn: Moreover it has not seen the sun or known anything; yet it finds rest rather than he. (6:5)

Perhaps the major reason why the knowledge that is available lacks value for Qohelet's concerns is its limited scope, that is, the lack of access to the unknown future, including death:

But all this I laid to heart, examining it all, how the righteous and the wise and their deeds are in the hand of God; whether it is love or hate man does not know. Everything before them is vanity $(9: 1)$

For the living know that they will die, but the dead know nothing, and they have no more reward; but the memory of them is lost (9:5)

Whatever your hand finds to do, do it with your might; for there is no work or thought or knowledge or wisdom in Sheol, to which you are going (9:10)

For man does not know his time. Like fish which are taken in an evil net, and like birds which are caught in a snare, so the sons of men are snared at an evil time, when it suddenly falls upon them $(9: 12)$

However, scope is not all that matters, and even unlimited knowledge about a given matter can prove unsatisfying. For example, what good is knowledge without power?:

For what advantage has the wise man over the fool? And what does the poor man have who knows how to conduct himself before the living? (6:8)

Whatever has come to be has already been named, and it is known what man is, and that he is not able to dispute with one stronger than he. (6:10)

For who knows what is good for man while he lives the few days of his vain life, which he passes like a shadow? For who can tell man what will be after him under the sun? (6:12)

In some sense, however, Qohelet can be aligned with the virtue epistemologist in that he did concern himself as much if not more with wisdom as an epistemological virtue than with conditions for knowledge.

\section{Qohelet and knowledge acquisition}

How, according to Qohelet, is knowledge acquired? This has been the focal point of traditional approaches to Qohelet's epistemology. In this regard, Qohelet's epistemology has often been described as empiricist. In philosophy, empiricism is generally a theory of knowledge focusing on the role of experience, especially experience based on perceptual 
observations by the senses. This is assumed to be present in Qohelet's references to what he 'saw':

1. Then I saw that wisdom excels folly as light excels darkness. (2:13)

2. This also, I saw, is from the hand of God. (2:24)

3. Moreover I saw under the sun that in the place of justice, even there was wickedness, and in the place of righteousness, even there was wickedness. (3:16)

4. So I saw that there is nothing better than that a man should enjoy his work, for that is his lot; who can bring him to see what will be after him? (3:22)

5. Again $I$ saw all the oppressions that are practiced under the sun. $(4: 1)$

6. Then I saw that all toil and all skill in work come from a man's envy of his neighbor. This also is vanity and a striving after wind. (4:4)

7. Again, I saw vanity under the sun. (4:7)

8. I saw all the living who move about under the sun, as well as that youth, who was to stand in his place. (4:15)

9. Then I saw the wicked buried. (8:10)

10 . ... then I saw all the work of God, that man cannot find out the work that is done under the sun. $(8: 17)$

11. Again I saw that under the sun the race is not to the swift, nor the battle to the strong, nor bread to the wise, nor riches to the intelligent, nor favor to the men of skill; but time and chance happen to them all. (9:11)

Not all these 'observations' can strictly be called empirical (or even experiential) in as much as Qohelet did not literally see them with his own eyes but instead only 'understood' their implications upon reflection on what he probably had only 'heard'. Also, there are many variants of empiricism, positivism and realism amongst the most commonly expounded, but central to all empiricist epistemologies is the notion of the epistemologically privileged status of sense data. In this sense, it does not make sense to say that Qohelet is an observer, as opposed to, say, a thinker. Be that as it may, let us for the moment assume that Qohelet did rely on experiences of all sorts. To call him an empiricist when it comes to epistemological sources would be too broad for a comprehensive epistemological analysis. Additional distinct epistemological sources can be identified, for example perception, introspection, memory, reason and testimony:

1. According to Qohelet's direct realism, we can acquire knowledge through perception because we can directly perceive such objects. For example, when Qohelet sees something under the sun, what he perceives is the thing itself.

2. Introspection in Qohelet refers to the capacity to inspect the, metaphorically speaking, 'inside' of one's heart (mind). Through introspection, Qohelet knows his own mental states: whether he is tired, excited or depressed. When it comes to introspection, for Qohelet, there is no difference between appearance and reality; therefore, introspection is necessarily successful.

3. Memory in Qohelet is the capacity to retain knowledge acquired in the past. What Qohelet remembers, though, needs not be a past event. It may for him be a present fact, such as his latest conclusion, or a future event, such as the onset of old age. It does not seem that Qohelet finds memory fallible at all.

4. Reason is also a source of knowledge in Qohelet. Yet Qohelet is no rationalist in the sense of believing reason to be the only source of knowledge. What makes reason important for Qohelet is its role in making sense of experience. For whilst his expression of insights may not cohere, his deductions based on specific observations certainly do rely on reason to come to specific conclusions, if assumptions were shared.

5. Qohelet also relies on testimony as he often reiterates, repeats or quotes an idea from the sapiential tradition and that is not based so much on experience as on theological claims:

'I know that whatever God does endures forever; nothing can be added to it, nor anything taken from it; God has made it so, in order that men should fear before him (3:14)'.

Qohelet, like all other people, seems to have accepted testimonial sources as reliable and tends to attribute credibility to them unless he encountered special contrary reasons.

Ultimately, Qohelet's epistemology cannot and should not be reduced to modernist categories like individualism (autonomy) and empiricism, not only because these are anachronistic but because they are misleading. All human views of knowledge presuppose the use of reason and experience so that in as much as Qohelet is doing the same, it is nothing special. The same goes for when Qohelet's emphasis on his own discoveries are taken to be defining and linked to the autonomy of the Cartesian subject. This too must be considered anachronistic. Qohelet refers to what he discovered not because his epistemology is individualist but because he speaks as a sage where first person rapports are an accepted form of expression (see Proverbs' references to the individual I).

\section{Qohelet, the structure of knowledge and the regress problem}

Now I turn to possible perspectives in Qohelet regarding the structure (as opposed to conditions or sources) of knowledge and justified belief. The basic epistemological problem is that, to justify a belief, one must appeal to a further justified belief. This means that one of two things can be the case. Either there are some (epistemologically basic) beliefs that we can be justified for holding, without being able to justify them on the basis of any other belief, or else there is an infinite regress of (potential) justification for each justified belief. In view of this, one or more of the various types of chains of reasoning that seek to escape the regress problem may be sought in Qohelet's epistemological assumptions:

1. It seems unlikely that Qohelet would have assumed that an infinite justificatory series existed, namely 'infinitism'.

2. It might be that Qohelet was a foundationalist if he would respond to the regress problem by asserting that certain 
'foundations' or 'basic beliefs' support other beliefs but do not themselves require justification from other beliefs because they are self-evident, infallible or derived from reliable cognitive mechanisms. Perception, memory and a priori intuition are often considered by Qohelet to be possible examples of basic beliefs.

3. Another possible response I need to compare with Qohelet is coherentism, which is the rejection of the assumption that the regress proceeds according to a pattern of linear justification and that an individual belief is justified circularly by the way it fits together (coheres) with the rest of the belief system of which it is a part.

4. A more recently theorised position is known as 'founherentism' and is meant to be a unification of foundationalism and coherentism. It is unlikely that Qohelet assumed this view.

5. A popular yet technically tricky position is that Qohelet was a sceptic in the epistemological sense that, for him, the belief in something does not necessarily justify an assertion of knowledge thereof. In this, he opposes foundationalism, which states that there have to be some basic beliefs that are justified without reference to others. Perhaps one could distinguish between Qohelet's assumptions regarding knowledge and his ideas on what can be known. The fact is that Qohelet does not come across as a sceptic with regard to knowledge as such he seems to know too much and has too much faith in what he knows. What he is sceptic about is the value of knowledge and its limits:

When I applied my mind to know wisdom, and to see the business that is done on earth, how neither day nor night one's eyes see sleep; then I saw all the work of God, that man cannot find out the work that is done under the sun. However much man may toil in seeking, he will not find it out; even though a wise man claims to know, he cannot find it out. (8:16-17)

A fool multiplies words, though no man knows what is to be, and who can tell him what will be after him? (10:14)

As you do not know how the spirit comes to the bones in the womb of a woman with child, so you do not know the work of God who makes everything (11:5)

Of course, it might be argued that, here, Qohelet is not a sceptic in the philosophical sense in that he does not deny the certainty of all knowledge. He is merely using knowledge, in which he believes, to point out the limits of valid knowledge and justified belief.

\section{Conclusion}

Many more epistemological issues could be brought to bear on Qohelet's thought, yet the above must suffice for now. In sum then, whilst a number of studies have seen the light concerning the epistemology of the book of Ecclesiastes during the last few decades, the available research has consistently adopted an 'inside-out' approach that is, reading Qohelet's words about knowledge and then seeking to link his thoughts on the matter to a particular epistemological stance. In this study, however, an 'outside-in' approach was opted for that involved noting all the various issues in epistemology and comparing each with what, if anything, Qohelet assumed in relation to the specific matter at hand. In doing so, it was shown why and how the available scholarship on the epistemology of Qohelet has left out a host of philosophical concerns and theories that can be brought to bear on the discussion. Only through such a more comprehensive, descriptive and purely philosophical approach can justice be done to the attempt at ascertaining how Qohelet relates to the whole array of epistemological perspectives in contemporary analytic philosophy.

\section{Acknowledgements Competing interests}

The author declares that he has no financial or personal relationships which may have inappropriately influenced him in writing this article.

\section{References}

Audi, R., 2005, Epistemology: A contemporary introduction to the theory of knowledge, Routledge, London \& New York.

Bartholomew, C., 1998, 'Qoheleth in the canon?: Current trends in the interpretation of Ecclesiastes', Themelios 24(3), 4-20.

Bartholomew, C., 2009, Ecclesiastes, Eerdmans, Grand Rapids. (Baker Bible Commentary Series)

BonJour, L., 2010, Epistemology: Classic \& contemporary responses, Rowman \& Littlefield, Lanham.

Braun, R., 1973, Kohelet und die fruehellenistische Popularphilosophie, de Gruyter, Berlin. (Beihefte Zur Zeitschrift Fur die Alttestamentliche Wissenschaft 130)

Crenshaw, J.L., 1984, A whirlpool of torment: Israelite traditions of God as an oppressive presence, Fortress Press, Philadelphia.

Crenshaw, J.L., 1998, 'Qohelet's understanding of intellectual inquiry,' in A. Schoors (ed.), Qohelet in the context of wisdom, pp. 204-224, Leuven University Press/ Peeters, Leuven. (Bibliotheca Ephemeridum Theologicarum Lovaniensium 136)

Dancy, J. \& Sosa, E. (eds.), 1993, A companion to epistemology, Blackwell, Oxford. http://dx.doi.org/10.1111/b.9780631192589.1993.x

Descartes, R., 1641, Meditations on first philosophy, reprinted in The philosophical writings of Descartes, 3 vols, Cambridge University Press, Cambridge.

Enns, P., 2011, Ecclesiastes, Eerdmans, Grand Rapids.

Fox, M.V., 1987, 'Qohelet's epistemology', Hebrew Union College Annual 58, 137-156. Fox, M.V., 1989, Qohelet and his contradictions, Sheffield Academic Press, Sheffield.

Fox, M.V., 1998, 'The inner structure of Qohelet's thought', in A. Schoors (ed.), Qohelet in the context of wisdom, pp. 225-38, Leuven University Press/Peeters, Leuven. (Bibliotheca Ephemeridum Theologicarum Lovaniensium 136)

Fox, M.V., 1999, A time to tear down and a time to build up: A rereading of Ecclesiastes, Eerdmans, Grand Rapids.

Frydrych, T., 2002, Living under the sun: Examination of Proverbs \& Qoheleth, Brill, Leiden.

Gettier, E., 1963, 'Is justified true belief knowledge?', Analysis 23, 121-123. http:// dx.doi.org/10.1093/analys/23.6.121

Hengel, M., 1974, Judaism and Hellenism: Studies in their encounter in Palestine during the Early Hellenistic Period, SCM Press, London.

Hume, D., 1751, An enquiry concerning human understanding, Hackett, Indianapolis.

Imray, K., 2009, Qohelet's philosophies of death, DPhil Thesis, Faculty of Arts and Education, Murdoch University.

Locke, J., 1689, An essay concerning human understanding, Clarendon, Oxford.

Nordheimer, I., 1838, 'The philosophy of Ecclesiastes', American Biblical Repository $12,197-219$.

O'Dowd, R., 2009, The wisdom of Torah: Epistemology in Deuteronomy and the wisdom literature, Vandenhoeck \& Ruprecht, Gottingen. (Forschungen zur Religion und Literatur des Alten und Neuen Testaments 225)

Pfeiffer, R.H., 1934, 'The peculiar scepticism of Ecclesiastes', Journal of Biblical Literature 53, 100-109. http://dx.doi.org/10.2307/3259877

Pinker, A., 2013, 'Ecclesiastes, Part II: Themes', Jewish Bible Quarterly 41(3), 163-170.

Plato, 1997, 'Meno', in J.M. Cooper (ed.), Plato: Complete works, pp. 870-897, Hackett Publishing Co., Indianapolis.

Pollock, J. \& Cruz, J., 1999, Contemporary theories of knowledge, 2nd edn, Rowman and Littlefield, Lanham.

Ranston, H., 1925, Ecclesiastes and the Early Greek wisdom literature, Epworth, London. 
Russell, B., 1910-11, 'Knowledge by acquaintance and knowledge by description', Proceedings of the Aristotelian Society 11, 108-128.

Schellenberg, A., 2002, Erkenntnis als Problem: Qohelet und die alttestamentliche Diskussion um das menschliche Erkennen, Vandenhoeck \& Ruprecht, Göttingen. (Orbis Biblicus et Orientalis 188)

Schoors, A. (ed.), 1998, Qohelet in the context of wisdom, Leuven University Press/ Peeters, Leuven. (Bibliotheca Ephemeridum Theologicarum Lovaniensium 136)

Sciumbata, M.P., 1996, 'Peculiarita e Motivazioni della Struttura Lessicale dei Verbi della 'Conoscenza' in Qohelet: Abbozzo di una storia dell'epistemologia ebraicobiblica', Henoch 18, 235-249.

Sneed, M., 2012, Ecclesiastes and the politics of pessimism, SBL Press, Atlanta.
Steup, M., 2005, 'Epistemology', in E.N. Zalta (ed.), The Stanford Encyclopedia of Philosophy, viewed 12 October 2014, from http://plato stanford.edu/archives/ spr2014/entries/epistemology/

Steup, M. \& Sosa, E., (eds.), 2005, Contemporary debates in epistemology, Blackwell, Malden.

Truncellito, D.A., 2007, 'Epistemology', in The Internet Encyclopedia of Philosophy, viewed 21 November 2014, from http://www.iep.utm.edu/

Weeks, S., 2012, Ecclesiastes and scepticism, T \& T Clark, New York. (Library of Hebrew Bible/Old Testament Studies 541)

Wolterstorff, N., 1999, 'Epistemology of religion', in J. Greco \& E. Sosa (eds.), The Blackwell guide to epistemology, pp. 303-324, Blackwell, Oxford. 